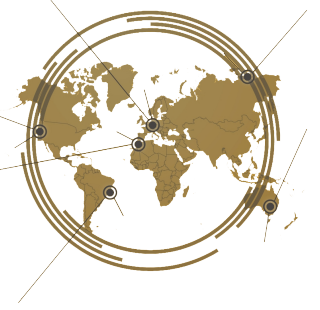

\title{
Critical thinking in cognitive domain: Exploring assessment of English teaching at pandemic period of covid-19
}

\author{
Akib Erwin*, Muh. Arif Muhsin \\ English Department, Universtas Muhammadiyah Makassar, Indonesia
}

Assessment is an evaluation tool in learning adjusted to the times. The criteria that must be included in the assessment are indicators in the cognitive domain and critical thinking. Therefore, this study intends to explore teaching assessments prepared by lecturers in assessing students' cognitive shutter and critical thinking abilities. The data taken in the pandemic period of Covid-19. The subjects of this study were 269 lecturers who were teaching in English education departments in some private universities in South Sulawesi, Indonesia. There were 25 items of questionnaires arranged to analyze the teacher assessment in cognitive aspects. The results showed the dominant lecturer measured the ability of students on the C1-C2 scale even though some lecturers had been on the C5-C6 scale. The lecturers' assessment of teaching has implemented indicators of critical thinking skills. This study recommends future researchers to develop assessment of teaching, especially for English Department and assessment mapping in facing the fourth industrial revolution era.

Keywords: Assessment, Teaching, Cognitive, Critical Thinking

\section{INTRODUCTION}

The $21^{\text {st }}$ century learning requires everyone to learn and think, focusing on developing intellectual abilities so that they can adapt to changing and changing times. The outcome in 21 stcentury learning is to have life and career skills. These skills are the ability to synthesize information, work as a team, to manage broadly and complexly, and be responsible to the community and the environment Balasubramanian et al. (2014). Expertise in technology, media and knowledge is the ability to recognize, discover and see all information with technology and media so that they can be meaningful Kietzmann et al. (2011). In contrast, critical learning skills and innovation are the ability to clarify understanding of a problem to produce logical decisions.

There are some previews study of cognitive domain in teaching assessment, the first was carried out by Bennett et al. (2016). The research explained how cognitive theory and principles are used in the design of scenario-based summative assessments for argumentation in the English arts. The results of the psychometric approach are used to evaluate the propositions suggested by domain theory, thus the use of learning development scenarios in the assessment design is interrelated. The study was continued by Boers (2013), collectively, the reported experiments were still starting to become a body of evidence supporting Cognitive Linguistic-informed instruction is hard to ignore. The next study is from Zareian et al. (2015) concluded that textbooks failed to engage students in questions that required a higher cognitive level. 
The other study was done by Setiawan and Bharati (2018), they concluded that the implementation of the project- basedspeaking assessment succeeded in stimulating students' critical thinking and creativity in learning English. Although several researchers have revealed the role of the cognitive domain in assessment, no one has explored the ability of lecturers to prepare critical thinking assessments in the cognitive realm, especially in Indonesia. The authenticity of this study aims to explore the assessments prepared by English lecturers as a second language during the pandemic of Covid-19.

Global competition in the digital age requires more than mastery of science, but also the acquisition of a variety of skills including critical thinking skills, problem-solving, communicating, collaborating, creating, literacy, and awareness of global issues Turiman et al. (2012) Voogt et al. (2013). The 21 st century requires a generation of critical thinkers who can solve problems and participate actively in making decisions on local and global issues that formed through thought processes Ampuero et al. (2015). The ability to think critically can be trained through learning that prioritizes the thought process.

The thinking process is an activity that involves the work of the brain, feelings and human will that can be seen through learning that focuses on student activities, whether visual, audio, kinesthetic, or verbal actions. In the process of thinking, individuals make connections between objects that are the main problem with the parts of knowledge they already have. Role of knowledge is everything that has obtained in the form of understandings. According to Bloom (1959), the thought process is divided into two, namely: Low Order Thinking Skills, namely the low order thinking in the $\mathrm{C} 1-\mathrm{C} 2$, middle in the $\mathrm{C} 3$ C4, and High Order Thinking Skills, namely the ability to think about the realm of $\mathrm{C} 4-\mathrm{C} 6$. This thought process made in the form of a taxonomy consisting of knowledge (C1), understanding (C2), application (C3), analysis (C4), evaluation (C5), and creating (C6).

Implementing assessment of teaching in a pandemic situation compels all educators did through a virtual system. Lecturers constructed their assessment base on their department program Nilson (2016). They made in the last semester by applying the cognitive approach combined with teaching materials. Akib and Arief (2019)stated that assessment is a data collection process in teaching focused on making decisions of students' ability in a subject. Assessment of teaching arranged to join government instruction in a pandemic situation.

Performance assessments are very well-used to assess reasoning. We can use an issue to both individual and group students and then assess their critical thinking skills Kennedy (2007) Birgili (2015). In addition to performance assessments, we can also investigate student reasoning through personal communication by asking strategic questions. Or we can include students to design essay scoring criteria, performance assessment scoring criteria, or a list of essential stages in the thought process. In that way, the teacher can at least assess student responses and how each student's reasoning Russ et al.
(2009). Because they internalize their vision and reflect on their work, they will become critical thinkers.

This study was structured to describe the preparation of teaching assessments in the cognitive realm, especially to see the ability of the test to reveal students' critical thinking in English. Good assessment is an assessment that emphasizes the ability of logic and reasoning students Sibbald (2011). Good assessment must fulfill cognitive elements which synchronized with critical thinking aspects Putri and Istiyono (2017). Assessment is a tool used to measure students' cognitive abilities that are developed based on the progress of the times. Assessments developed to meet the needs of the education unit, including the curriculum. This study aimed to determine the implementation of learning assessments based on critical thinking.

Assessment is the process of gathering information about students and classes for instructional decision-making purposes. Assessment means the process of gathering information. For teachers, the assessment carried out as a goal of deciding teaching skills Oakleaf (2009). Assessment is the process of gathering information by using appropriate tools and techniques, to make educated decisions regarding the placement and educational programs for certain students Nieto (2000). Assessment or appraisal interpreted as an activity of interpreting measurement data based on specific criteria or rules Sadler (2005). Assessment is the process of gathering information about objects (students) using appropriate tools and techniques to make judgments or decisions about the object. It is necessary to have a tool or instrument and method to gather information and evaluate reports about objects to conduct an assessment.

Instruments for assessment are called tests. The test used is a measuring instrument and information about the object. The test is one way to estimate the size of a person's ability indirectly, namely through one's response to stimuli or questions von Borell et al. (2007). A test is a tool or procedure used to find out or measure something in an atmosphere, by means and rules have determined Sadler (2009). The test is one tool for measuring, which is a tool for gathering information on the characteristics of an object Casler et al. (2013) Chawla and Orso (2004). It concluded that the test is a method or tool (instrument) and the technique used to obtain object information (students) in the form of an assignment with specific rules. The function of the test is as a measurement and information collector for assessment and evaluation.

Harlen (2013)stated purpose of assessment is keeping track, checking-up, finding-out, and summing-up". Keeping track, which is to trace and track the learning process of students following the planned learning implementation. For this reason, the teacher must collect data and information in a certain period through various types and assessment techniques to obtain a picture of the achievement of student learning progress. Checking-up, which is to check the achievement of students' abilities in the learning process and the shortcomings of students during the learning process. In other words, the teacher needs to assess to find out which parts of the material students have mastered and which sections of the material 
have not been mastered. Finding-out, which is to search for, find and detect the lack of mistakes or weaknesses of students in the learning process, so that teachers can quickly find alternative solutions. Summing-up, which is to conclude the level of mastery of students of the competencies that have been determined. The results of this conclusion can be used by teachers to compile reports on learning progress to various interested parties.

Assessment is an evidence-gathering activity that is carried out intentionally, systematically, and continuously and is used to assess student competencies. The reasoning is the process of thinking ability of a person to gain new knowledge by way of the logic of the concepts he knows based on the available evidence and contradicts it with previous expertise Handayati and Ritme (2014). The reasoning also has the relationships between experience and knowledge that a person uses to explain what is seen, thought and concluded. Reasoning is a thinking process in drawing conclusions in the form of knowledge, it produces knowledge associated with thinking activities. It can be said that reasoning assessment is a deliberate collection of evidence to make connections between experience and knowledge to explain what is seen, thought and concluded.

Norris and Ennis (1989) and Ennis (1993) reveal a set of stages that includes the process of critical thinking. The first is larify the issue by asking critical questions, the second is gather information about the issue, the third is starting the reasoning through various sides or different points of view, the fourth is gathering information and conduct further analysis, if needed, and the fifth is making and communicating decisions

In additio to developing critical thinking related to the cognitive domain, Norris and Ennis also developed a disposition which is a "critical soul". The following will describe the abilities and critical dispositions of Harlen (2013). Ennis (2001) stated that critical thinking is reasonable and reflective thinking that is focused on making decisions about what is done or believed. Reasonable means thinking based on facts to produce the best decision, reflective means to search consciously and decisively the best possible solution. Thus, critical thinking, according to Norris and Ennis is thinking directed to the goal. The purpose of critical thinking is to evaluate the best actions or beliefs. Norris and Ennis focus their framework on the thought process that involves gathering information and applying criteria to consider a different set of actions or views. This corresponds to the level of evaluation thinking in Bloom's taxonomy.

As Ennis view, the conceptual framework offered by Marzano (1250) includes cognitive and affective components. The cognitive dimension (of Marzano's relatively complex arrangement) describes the reasoning process. The affective dimension states that students must develop and maintain positive attitudes and perceptions about learning and understanding personal responsibility for wise thinking. If this affective dimension is not possessed, then it seems that the skills they have been in vain.

The advantage of this framework is each type of thinking specified naturally translated into questions that seem to apply to all material areas. Furthermore, each question seems unique and relevant to the real world based on critical thinking aspects. The assessment of teaching must show essential elements of thinking in the pandemic period.

\section{METHOD}

The study conducted in English Education Department of Muhammadiya's university and academy in South Sulawesi. There are five universities and six academies belonging to Muhammadiyah which are located in eleven cities and districts. There were eleven English Departments as the object of the study including in Makassar with 51 lecturers, Bulukumba with 33 lecturers, Sinjai with 32 lecturers, Bone with 34 lecturers, Barru with 10 lecturers, Enrekang with 11 lecturers, Sidrap 20 lecturers, Pare-Pare with 53 lecturers, Luwu with 8 lecturers, Palopo with 9 lecturers, and Jeneponto with 8 lecturers. There were 269 lecturers as respondents of the study by same background education in English.

The study used 25 number of the questionnaire. The questionnaire used has been validated by a team of experts at the University of Muhammadiyah Makassar. Valid questionnaires are used to collect data in this study. The questionnaires included cognitive skill based on Bloom (1959) and aspects of critical thinking like 1) able to provide simple explanations such as, focusing questions, analyze arguments, ask and answer about an explanation or challenge. 2) able to conclude, 3) able to interpret facts or conclusions or logical statement based on information provided; and 4) evaluation, distinguish between strong and relevant arguments and Weak or irrelevant arguments.

Google form was used as questionnaires tool to collect the data in a pandemic of Covid-19 situation. Questionnaire created by closed and a combination of open and closed questionnaires. The main purpose this questionnaire is to obtain relevant information with the aim of investigating and obtaining information with road reliability and validity as possible. The survey of questionnaire used to assess the lecturers' performance applying critical thinking in their assessment.

\section{RESULT AND DISCUSSION}

\section{Assessment of Teaching in Cognitive Domain}

In designing learning assessments during the pandemic, lecturers required to adjust the conditions and according to the times. The results of data analysis showed that the lecturer had made an assessment with Bloom (1959) scale in the cognitive domain. 

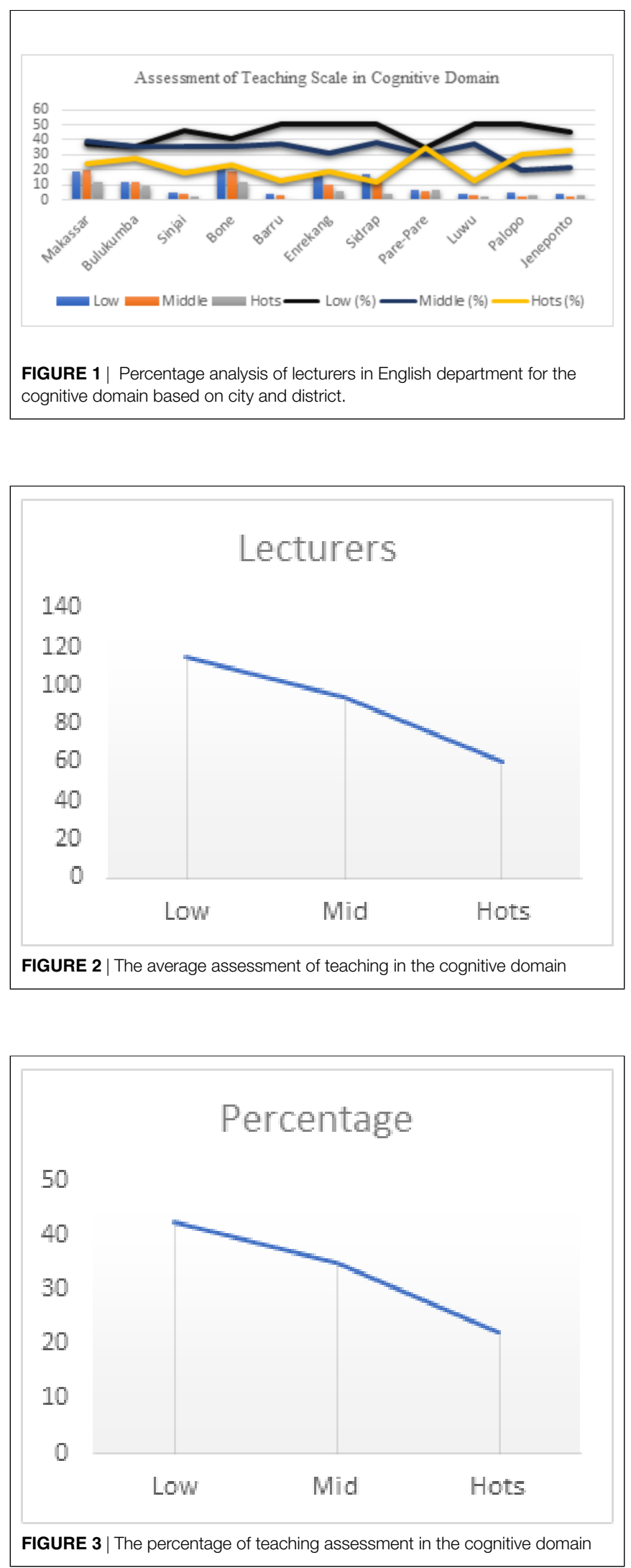

In creating the assessment of teaching, lecturers used some verbs which can be classified in C1-C6. Operational verbs in the cognitive domains widely used from survey results are shown in the following Table 1.

TABLE 1 | Operational verbs used in the assessment of teaching for the cognitive domain

\begin{tabular}{cl}
\hline Cognitive domain & Operational verbs \\
C1 & Identifying, writing, and Mentioning \\
C2 & Example, characterize and describe \\
C3 & Expressing and sorting \\
C4 & Concluding, studying, and analyzing \\
C5 & Arranging dan Explaining \\
C6 & Clarifying and creating \\
\hline
\end{tabular}

Table 1 shows some of the operational verbs used in preparing the assessment by the lecturers. The verb is the most familiar in the evaluation sentences in education. Learning assessment can be classified based on Bloom's taxonomy, which starts at C1-C6.

\section{Assessment of Teaching based Critical Thinking}

Assessment of teaching based on critical thinking skills, the lecturers have used the indicators of critical thinking criteria. The assessment is compiled process, examines the material and provides criticism. The results of a learning assessment survey based on critical thinking skills are shown in the Table 2 .

TABLE 2 | Indicators of critical thinking applied in the assessment of teaching.

\begin{tabular}{|c|c|c|c|c|c|}
\hline & Indicators & Yes & No & $(\%)$ & (\%) \\
\hline 1. & Simple explanation & 217 & 52 & 80.7 & 19.3 \\
\hline 2. & Reviewing Questions & 174 & 95 & 64.7 & 35.3 \\
\hline 3. & Analyzing arguments & 114 & 155 & 42.4 & 57.6 \\
\hline 4. & Ask and answer an explanation & 235 & 34 & 87.4 & 12.6 \\
\hline 5. & Analyze and conclude & 128 & 141 & 47.6 & 52.4 \\
\hline 6. & $\begin{array}{l}\text { Make statements accompanied } \\
\text { by scientific facts }\end{array}$ & 239 & 30 & 88.8 & 11.2 \\
\hline 7. & Read and give criticism & 158 & 111 & 58.7 & 41.3 \\
\hline 8. & Evaluating arguments & 134 & 135 & 49.8 & 50.2 \\
\hline 9. & $\begin{array}{l}\text { Compare arguments between } \\
\text { hoax facts }\end{array}$ & 127 & 142 & 47.2 & 52.8 \\
\hline 10. & $\begin{array}{l}\text { Reviewing the work that has } \\
\text { been made }\end{array}$ & 219 & 50 & 81.4 & 18.6 \\
\hline
\end{tabular}

Table 2 showed the indicators that have been used by lecturers in developing learning assessments. There are ten indicators used as benchmarks to determine the implementation of critical thinking in the assessment.

Based on the data obtained, there are four indicators of critical thinking that are most often used by lecturers. The first indicator of explaining simply in the assessment, there were 217 or $80.7 \%$ of lecturers who used it, and only 52 or $19.3 \mathrm{did}$ 
not use it. The second indicator is asking and answering an explanation, 235 or $87.4 \%$ of lecturers use it as an indicator, and only 34 or $12.6 \%$ do not use the indicator. The third indicator is making a statement accompanied by scientific facts, 239 or $88 \%$ of the lecturers apply this indicator in the assessment, and only 30 or $12 \%$ do not use it in the assessment. The fourth indicator is examining the work created, 219 or $81.4 \%$ who use it and 50 or $18.6 \%$ who do not use it as a criterion

Assessment in learning is a tool to measure student ability and as a reflection of learning outcomes. The cognitive shutter is an absolute element that must be present in the assessment, which includes low, medium and high-level capabilities based on bloom taxonomy Nilson (2016). In addition, indicators of critical thinking are also one aspect that must be present in the assessment as a 21 st-century skill. The assessment instrument that is widely used by lecturers is an instrument in the form of written test questions. The preparation of questions is not easy, there are rules and procedures that are followed by lecturers.

The ability of lecturers to develop critical learning-based learning assessments has been implemented in learning. This is erased from the results of the analysis conducted on the lecturer. They have included components of lower-order thinking, middle-order thinking, and higher-order thinking. In the cognitive domain, the lecturer uses several verbs that describe levels C1-C6. They also include indicators of critical thinking in the assessment. According to Alfindasari et al. (2016), the cognitive domain in assessment is a tool to measure the students' skill in learning. In the preparation of questions, the first thing to prepare is to make a question grid. In this question grid, the lecturer must determine the question indicators. This question indicator must be arranged correctly because it will reflect the questions to be made. In determining and making indicators of this question, there is something that needs to be considered by the teacher, namely the cognitive level as a note that must be achieved by students after learning.

Critical thinking is a 21 st-century skill that must be implemented in learning. Students will have a high sense of responsibility and skill that is needed by the world of work. By learning critical thinking in students, assessment tools must be adjusted to the indicators used in the classroom. Thus, there is harmony between the cognitive abilities of students and the assessment used in assessing. The strength of lecturers to arrange critical thinking assessments is quite high. This can be proven by the use of critical thinking theory which is widely used as a reference source. The research is supported by Birgili (2015); Handayati and Ritme (2014). They said critical thinking is finding relationships, connecting cause-effect, transforming, classifying and giving qualifications to build creative of students.

\section{CONCLUSION}

The results showed the lecturers' skill to compile learning assessment instruments was satisfactory in cognitive domain. It covered low order thinking, medium order thinking, and higher order thinking. The lecturers have considered the cognitive domain in the assessment by using operational verbs that indicate levels of C1-C6. Furthermore, the lecturers have used critical thinking indicators in compiling the assessment. Although they have considered cognitive factors and aspects of critical thinking, their abilities must still be developed because they tend to measure the low-order thinking level of students' abilities. The further research is expected to develop assessment mapping in the industrial revolution era. The main focus is correlated the assessment of English teaching with 4C skills (critical thinking, creativity, collaboration, and communication) and TPACK (technological, pedagogical, and knowledge content).

\section{ACKNOWLEDGMENTS}

The researchers would like to express gratitude to the Institute for Research, Development and Community Service (LP3M) University of Muhammadiyah Makassar who have provided funding for this research as well as education lecturers at the Teacher Training and Education Faculty who have helped fill out the research questionnaire.

\section{Appendix}

Direction: Choose two operational verbs sometime you use in constructing assessment of English department students.

1. The operational two verbs used for simple explanation are.......

- Match

- Explain

- Express

- Correct

- Arrange

- Classified

2. The operational verbs used in for complex explanation are.......

- Match

- Explain

- Classified

- Arrange

- Express

- Correct

3. The operational verbs used for examining the questions are.......

- Describe

- Classify

- Explain

- Conclude

- Choose

- Connect 
4. The operational verbs used in asking the students to make argumentation next are.......

- Create

- Write

- Specify

- Describe

- Find out

- Choose

5. The operational verbs used in analyzing an argumentative text are.......

- Show

- Write

- Classify

- Analyze

- Explain

- Connect

6. The operational verbs used in asking students explain the questions are......

- Develop

- Critic

- Find out

- Classify

- Explain

- Show

7. The operational verb used for explaining the answer are

- Explain

- Describe

- Classify

- Conclude

- Critic

- Develop

8. The operational verb used for concluding the materials are.......

- Identify

- Describe

- Determine

- Conclude

- Choose

- Create

9. The operational verb used for analyzing the essay are.......

- Write

- Describe

- Classify

- Analyze

- Compare

- Connect
10. The operational verb used for making statement are.......

- Explain

- Describe

- Classify

- Analyze

- Critic

- Create

11. The operational verb used for making statement accompanied scientific are.......

- Explain

- Describe

- Classify

- Analyze

- Critic

- Create

12. The operational verb used for critical reading are.......

- Write

- Tell

- Classify

- Correct

- Critic

- Combine

13.The operational verb used for reading and criticize are.......

- Describe

- Explain

- Classify

- Correct

- Critic

- Create

14. The operational verb used for exalting the text are.......

- Explain

- Giving Example

- Determine

- Conclude

- Critic

- Create

15. The operational verb used for evaluating an argument are.......

- Write

- Describe

- Conclude

- Determine

- Critic

- Create

16. The operational verb used for identifying argumentation text...... 
- Identify

- Describe

- Classify

- Conclude

- Choose

- Create

17. The operational verb used for evaluating argumentation are.......

- Write

- Express

- Classify

- Analyze

- Critic

- Combine

18. The operational verb used for criticize argumentation are.......

- Write

- Express

- Apply

- Correct

- Critic

- Combine

19. The operational verb used for expressing opinion are...... Write

- Describe

- Express

- Analyze

- Choose

- Connect

20. The operational verb used for explaining narration are.......

- Describe

- Explain

- Determine

- Analyze

- Compare

- Create

21. The operational verb or used for examining the news are.......
- Describe

- Explain

- Express

- Analyze

- Compare

- Connect

22. The operational verb used for describing event are.......

- Describe

- Explain

- Express

- Connect

- Compare

- Create

23. The operational verb used for examining scientific paper are.......

- Connect

- Compare

- Analyze

- Classify

- Describe

- Show

24. The operational verb used for criticize hoax are.......

- Write

- Show

- Describe

- Correct

- Compare

- Evaluate

25. The operational verb used for measuring argumentation are.......

- Write

- Explain

- Express

- Analyze

- Compare

- Connect

\section{REFERENCES}

Akib, E. and Arief, M. (2019). Assessment of Teaching in 21st Century. Journal of Physics: Conference Series 1, 1179.

Alfindasari, D., Paidi, P., and Yulaikah, S. (2016). Development Instruments Dimension Cognitive Anderson-Krathwol In Biology Learning Class Xi Of South Jakarta Senior High School. Proceeding of the International Conference on Teacher Training and Education 2, 422-436.

Ampuero, D., Miranda, C. E., Delgado, L. E., Goyen, S., and Weaver, S. (2015).

Empathy and critical thinking: primary students are solving local environmental problems through outdoor learning. Journal of Adventure Education \& Outdoor Learning 15, 64-78.

Balasubramanian, K., Jaykumar, V., and Fukey, L. N. (2014). A Study on "Student Preference towards the Use of Edmodo as a Learning Platform to Create Responsible Learning Environment". Procedia - Social and Behavioral Sciences 144, 416422. doi: 10.1016/j.sbspro.2014.07.311.

Bennett, R. E., Deane, P., and van Rijn, P. W. (2016). From Cognitive-Domain Theory to Assessment Practice. Educational Psychologist 51, 82-107. doi: 
$10.1080 / 00461520.2016 .1141683$.

Birgili, B. (2015). Creative and critical thinking skills in problem-based learning environments., and others (ed.).

Bloom, B. S. (1959). Taxonomi of Objectives: The Clasification of Education Goals., and others (ed.).

Boers, F. (2013). Cognitive Linguistic approaches to teaching vocabulary: Assessment and integration. Cognitive Linguistic approaches to teaching vocabulary: Assessment and integration. Language Teaching 46, 208-224.

Casler, K., Bickel, L., and Hackett, E. (2013). Separate but equal? A comparison of participants and data gathered via Amazon's MTurk, social media, and faceto-face behavioral testing. Computers in Human Behavior 29, 2156-2160. doi: 10.1016/j.chb.2013.05.009.

Chawla, A. and Orso, A. (2004). A generic instrumentation framework for collecting dynamic information. ACM SIGSOFT Software Engineering Notes 29, 1-4. doi: $10.1145 / 1022494.1022533$.

Ennis, R. H. (1993). Critical thinking assessment. doi: 10.1080/00405849309543594. https://dx.doi.org/10.1080/00405849309543594.

Ennis, R. H. (2001). Argument appraisal strategy: A comprehensive approach. Informal Logic 21. doi: 10.22329/il.v21i2.2240.

Handayati, P. and Ritme, A. (2014). The Development Of It-Based Assessment Database With Reinforcement On Accounting Subject At Senior High School. European Scientific Journal.

Harlen, W. (2013). Assessment \& Inquiry-Based Science Education. In Global Network of Science Academies (IAP) Science Education Program (SEP).

Kennedy, R. (2007). In-class debates: Fertile ground for active learning and the cultivation of critical thinking and oral communication skills. International Journal of Teaching \& Learning in Higher Education 19.

Kietzmann, J. H., Hermkens, K., McCarthy, I. P., and Silvestre, B. S. (2011). Social media? Get serious! Understanding the functional building blocks of social media. Business Horizons 54, 241-251. doi: 10.1016/j.bushor.2011.01.005.

Marzano, R. J. (1250). A different kind of classroom: Teaching with dimensions of learning. Association for Supervision and Curriculum Development (North Pitt Street, Alexandria, VA 22314 (ASCD stock), 611-92107.

Nieto, S. (2000). Placing equity front and centre: Some thoughts on transforming teacher education for a new century. Journal of teacher education 51, 180-187.

Nilson, L. B. (2016). Teaching at its best: A research-based resource for college instructors. (John Wiley \& Sons).

Norris, S. E. and Ennis, R. R. (1989). Evaluating Critical Thinking, and others (ed.).

Oakleaf, M. (2009). The information literacy instruction assessment cycle. Journal of Documentation 65, 539-560. doi: 10.1108/00220410910970249.

Putri, S. F. and Istiyono, E. (2017). The Development of Performance Assessment of Stem-Based Critical Thinking Skills in the High School Physics Lessons. International Journal of Environmental And Science Education 12, 1269-1281.
Russ, R. S., Coffey, J. E., Hammer, D., and Hutchison, P. (2009). Making classroom assessment more accountable to scientific reasoning: A case for attending to mechanistic thinking. Science Education 93, 875-891. doi: 10.1002/sce.20320.

Sadler, D. (2005). Interpretations of criteria-based assessment and grading in higher education. Assessment \& Evaluation in Higher Education 30, 175-194. doi: $10.1080 / 0260293042000264262$.

Sadler, D. R. (2009). Indeterminacy in the use of preset criteria for assessment and grading. Assessment \& Evaluation in Higher Education 34, 159-179. doi: 10.1080/02602930801956059.

Setiawan, A. and Bharati, D. A. L. (2018). Developing HOT Project-Based-Speaking Assessment to Stimulate the Students' Critical Thinking and Creativity. English Education Journal 8, 301-307.

Sibbald, D. (2011). Elective self-care course emphasizing critical reasoning principles. Elective self-care course emphasizing critical reasoning principles-American journal of pharmaceutical education 75, 75-75.

Turiman, P., Omar, J., Daud, A. M., and Osman, K. (2012). Fostering the 21st Century Skills through Scientific Literacy and Science Process Skills. Procedia-Social and Behavioral Sciences 59, 110-116. doi: 10.1016/j.sbspro.2012.09.253.

von Borell, E., Langbein, J., Després, G., Hansen, S., Leterrier, C., Marchant-Forde, J., et al. (2007). Heart rate variability as a measure of autonomic regulation of cardiac activity for assessing stress and welfare in farm animals - A review. Physiology \& Behavior 92, 293-316. doi: 10.1016/j.physbeh.2007.01.007.

Voogt, J., Erstad, O., Dede, C., and Mishra, P. (2013). Challenges to learning and schooling in the digital networked world of the 21 st century. Journal of Computer Assisted Learning 29, 403-413. doi: 10.1111/jcal.12029.

Zareian, G., Davoudi, M., Heshmatifar, Z., and Rahimi, J. (2015). An evaluation of questions in two ESP coursebooks based on Bloom's new taxonomy of cognitive learning domain. International Journal of Education and Research 3, 313-326.

Conflict of Interest Statement: The authors declare that the research was conducted in the absence of any commercial or financial relationships that could be construed as a potential conflict of interest.

Copyright $(2020$ Erwin and Muhsin. This is an open-access article distributed under the terms of the Creative Commons Attribution License (CC BY). The use, distribution or reproduction in other forums is permitted, provided the original author(s) and the copyright owner(s) are credited and that the original publication in this journal is cited, in accordance with accepted academic practice. No use, distribution or reproduction is permitted which does not comply with these terms. 